\title{
Oocyte development and ovarian maturation of the black triggerfish, Melichthys niger (Actinopterygii: Balistidae) in São Pedro e São Paulo Archipelago, Brazil
}

\author{
Ilka S. L. Branco ${ }^{1}$, Danielle L. Viana², Renata T. S. Félix³, Dráusio P. Véras² \\ and Fábio H. V. Hazin ${ }^{1}$
}

The oogenesis is a key stage in the reproductive development of an organism, which can be best understood from histological analysis of ovaries in different maturity stages. In order to provide information on the reproductive biology of the black triggerfish, M. niger, in particular on its oogenesis process, this study aimed at identifying and characterizing the oocyte development stages and its organization within the different stages of ovarian maturation based on specimens from São Pedro e São Paulo Archipelago. In this present report, a number of 294 ovaries were histologically analyzed. It was verified that they are composed of ovigerous lamellae containing oocytes at different development stages. Five different stages of oogenesis were identified: young cells, with an average size of $12.9 \mathrm{im}$; previtellogenic oocytes (perinucleolar), with an average size of $53.5 \mathrm{im}$; cortical-alveoli oocytes with an average size of $83.1 \mathrm{ìm}$; vitellogenic oocytes, with an average size of $160.4 \mathrm{imm}$ and mature oocytes, with an average size of $289.8 \mathrm{im}$. In addition to the germ cells, some somatic structures were also identified, such as: ovarian wall, follicular cells and blood vessels. Based on the type and number of oocytes observed, four stages of ovarian maturation were identified: early maturation, represented by only $2.2 \%$ of the sample; middle maturation, represented by $9.9 \%$; mature, represented by $44.2 \%$ and resting, represented by $43.9 \%$. The identification of five oocyte development stages in the ovarians from M. niger, suggested that the specie follows a pattern similar to that described for other marine fish.

A oogênese é um estágio chave no desenvolvimento reprodutivo de um organismo, o qual pode ser melhor compreendido a partir de análises histológicas dos ovários em diferentes estágios de maturidade. A fim de fornecer informações sobre a biologia reprodutiva do cangulo-preto, $M$. niger, em especial sobre o seu processo de oogênese, este estudo teve como objetivo identificar e caracterizar as fases do desenvolvimento ovocitário e sua organização dentro dos diferentes estágios de maturação ovariana, baseado em espécimes do Arquipélago de São Pedro e São Paulo. No presente estudo, um número de 294 ovários foram analisados histologicamente. Foi verificado que eles são constituídos por lamelas ovígeras contendo ovócitos em diferentes estágios de desenvolvimento. Foram identificados cinco diferentes estágios da oogênese: células jovens, com tamanho médio de 12,9 ìm; ovócitos pré-vitelogênicos (perinucleolares), com tamanho médio de 53,5 ìm; ovócitos alvéolocorticais, com tamanho médio de 83,1 ìm; ovócitos vitelogênicos, com tamanho médio de 160,4 ìm e ovócitos maduros, com tamanho médio de $289,8 \mathrm{ìm}$. Além das células germinativas, algumas estruturas somáticas também foram identificadas, tais como: parede do ovário, células foliculares e vasos sanguíneos. Baseado no tipo e número de ovócitos observados, quatro estágios de maturação ovariana foram identificados: início de maturação, representado por apenas 2,2\% da amostra; média maturação, representado por $9,9 \%$; madura, representado por $44,2 \%$ e em repouso representado por $43,9 \%$. A identificação de cinco estágios do desenvolvimento ovocitário nos ovários de M. niger, sugere que a espécie segue um padrão semelhante ao descrito para outros peixes marinhos.

Key word: Histology, Oogenesis, Reef fish, Reproduction, Vitellogenesis.

\footnotetext{
${ }^{1}$ Universidade Federal Rural de Pernambuco (UFRPE), Departamento de Pesca e Aquicultura, Laboratório de Oceanografia Pesqueira. Av. Dom Manuel de Medeiros s/n, Dois Irmãos, 52171-900 Recife, PE, Brazil. iilkabranco@hotmail.com (ISLB), fhvhazin@terra.com.br (FHVH)

${ }^{2}$ Universidade Federal de Pernambuco (UFPE), Departamento de Oceanografia, Av. Prof. Moraes Rego, 1235 - Cidade Universitária, 50670-901 Recife, PE, Brazil.vianad1@yahoo.com(DLV),drausioveras@hotmail.com (DPV)

${ }^{3}$ Universidade Federal Rural de Pernambuco (UFRPE), Departamento de Morfologia e Fisiologia Animal, Laboratório de Histologia. Av. Dom Manuel de Medeiros s/n, Dois Irmãos, 52171- 900 Recife, PE, Brazil. renatatfelix@hotmail.com (RTSF)
} 


\section{Introduction}

Most studies conducted so far on the reproductive biology of teleosts are related to macroscopic classification of maturity stages of gonads, gonadosomatic index (GSI), fecundity and reproductive behavior of species in natural environment, including mating and spawning behavior (Fricke, 1980; Hunter \& Macewicz, 1985; Kawase, 2003; Abascal \& Medina, 2005). More detailed studies, however, are necessary to achieve a proper understanding of how ovarian development occurs in these species. Histological analysis is an essential tool to reach this goal. It uses microscopic classification of developmental stages of ovaries, including their cytological characteristics, is especially important to identify the reproductive activity of tropical reef species, particularly during non-spawning periods (Tricas \& Hiramoto, 1989). Histological analysis of teleosts ovaries allows for a more precise evaluation of reproductive parameters (Hunter \& Macewicz, 1985) which might not be perceived by a macroscopic analysis alone, since gonads external appearance may not reflect the actual biological events taking place inside them (West, 1990; Honji et al., 2006). Although the oogenesis process has already been well described for some teleost species (Wallace \& Selman, 1981; McMillan, 2007), as of yet there is little information available on oocyte development of species of the family Balistidae, except for Balistes capriscus (Bernardes \& Dias, 2000).

Balistidae is characterized by a demersal spawning behavior, producing a large number of small adhesive eggs, which remain hidden, adhered to the bottom, in coral and algae (Thresher, 1980). Some species are distinguished by digging nests in the sand to lay their fertilized eggs (Lobel \& Johannes, 1980). In such cases, parental or biparental care during the eggs development is a hallmark of the group. Pseudobalistes flavimarginatus species, for example, has a biparental care for the fertilized eggs. While the female oxygenates the eggs by fanning water over them with pectoral fins, the male remains nearby, chasing small fish that approach the nest (Gladstone, 1994).

According to Bernardes \& Dias (2000), B. capriscus female, in turn, prepares a nest in the substrate while the male removes any unwelcome animal. The spawning usually occurs at the end of the day, with thousands of eggs forming a gray mass. After fertilization, the female and the male protect the eggs until they hatch, in a period of about 55 hours.

A similar behavior, described before by Bernardes \& Dias (2000) for B. capriscus female, was reported by Kawase (2003) for Xanthichthys mento, with the species spawning in pairs on sandy bottom and both, males and females, taking care of the eggs for two days until they hatched. Both males and females disappear from the territories after the larvae are born. The Adhesive eggs of Sufflamen chrysopterum, are deposited in the sandy bottom being consequently mixed with the sand. After spawning, the female fans the eggs and defends the nest until they hatch (Kawase \& Nakazono, 1992). Kuwamura (1997) also observed that females of Rhinecanthus aculeatus exhibit spawn adhesive demersal eggs, remaining "fixed" to the grains of sand, coral and filamentous algae. After spawning the female stays in the nest to take care of the eggs, while the male, visits other females. In this case, parental care is exercised exclusively by the mother.

Although some information on the reproductive behavior of the family Balistidae had already been reported by some authors, there is still a great lack of information about the reproductive cycle and models of the species of this family.

In general, fish reproductive behavior is related to their distribution on the oceans and in the water column. The black triggerfish, M. niger (Bloch, 1786), for example, is one of the least-known species of the family Balistidae, mainly due to its strictly oceanic and insular distribution. The black triggerfish has a circumtropical distribution (Carvalho-Filho, 1999), in the Atlantic Ocean, with occurrence records in the Navassa Island, Caribbean Sea (Grace et al., 2000); Monjes Archipelago, in Venezuela (Fariña et al., 2005) Fernando de Noronha Archipelago (Sazima et al., 2006), Trindade Island (Gasparini \& Floeter, 2001), on the central (Martins et al., 2007) and northeast coast of Brazil (Feitosa et al., 2005), as well as other locations.

Unlike other Balistidae family members, which usually live solitary (Kavanagh \& Olney, 2006), the black triggerfish form large shoals (Price \& John, 1980). There are, however, differences in local population density and aggregation behavior. According to Kavanagh \& Olney (2006), on their study about ecological correlations in population density, the black triggerfish demonstrated high population density in Johnston Atoll located between the Hawaiian Island and Marshall Islands, with the largest group containing more than 500 individuals. While in Belize barrier reef, there was rarely more than 10 fish in a group.

Despite its great ecological importance to island ecosystems, there is little information about the biology of this species. In order to overcome this deficiency, the present study aimed to identify and characterize the oocyte development stages of black triggerfish and its organization throughout the different stages of ovarian maturation, based on specimens from São Pedro e São Paulo Archipelago (SPSPA), area in which the species usually spawns seasonally, especially in the first semester of the year (Branco, 2011).

\section{Material and Methods}

All specimens examined in this study were collected by tuna fishing boats from the city of Natal-RN. The boats operate in the region around São Pedro e São Paulo Archipelago (Fig. 1), located in the North Atlantic Ocean near the Equator $\left(00^{\circ} 55^{\prime} \mathrm{N} 29^{\circ} 21^{\prime} \mathrm{W}\right)$, at a distance of approximately $1,100 \mathrm{~km}$ from the Brazilian coast (Hazin et al., 2008). Between January 2006 and May 2008, the ovaries of 294 black triggerfish females, caught by a scoop net. They were collected monthly with an average of 25 specimens per sampling.

All the samples were first attracted to the surface using other fish viscera as bait and then captured randomly. The caught specimens were immediately placed in a container with ice. The spinal cord section was executed and then the bleeding by cutting the gills. All the organisms were killed according to the institutional 


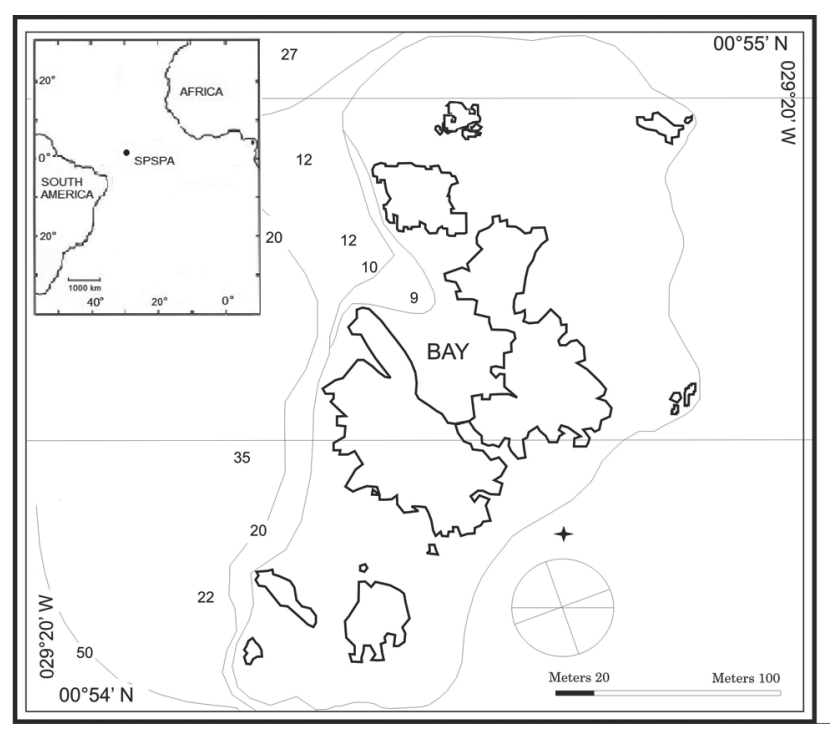

Fig. 1. Geographical location and map of the São Pedro e São Paulo Archipelago.

animal care protocols and approval. The ovaries and histological slices are kept in the Laboratório de Oceanografia Pesqueira (LOP), Departamento de Pesca e Aquicultura/UFRPE.

Soon after boarding, specimens were identified and the total length -TL $(\mathrm{cm})$ and the standard length - SL $(\mathrm{cm})$ were measured. Subsequently, the reproductive system of all samples were collected, frozen and transported to the laboratory. Once there, the weight $(\mathrm{g})$ of the ovaries and their respective length and width were measured, and they were macroscopically analyzed, to identify the maturational stage. Afterwards, they were fixed in $10 \%$ formaldehyde solution for 48 hours, and then transferred to $70 \%$ ethanol solution.

The gonad index (GI) was calculated by Schaeffer \& Orange (1956), as follows: $\mathrm{GI}=\mathrm{GW} / \mathrm{TL}^{3} \times 10^{5}$, where: $\mathrm{GI}=$ gonad index, $\mathrm{GW}=\operatorname{gonad}$ weight $(\mathrm{g})$ and $\mathrm{TL}=$ total length $(\mathrm{cm})$.

In order to determine the stage of development of the germ cells and ovaries maturation, a $1 \mathrm{~mm}^{3}$ section was obtained from the middle portion of the ovary, dehydrated and embedded in paraffin at $60^{\circ} \mathrm{C}$ (Behmer et al., 1976). Paraffin blocks were cut in 6 im sections, which were then stained with hematoxylineosin (HE) and examined under a light microscope.

According to the oocyte shape and nucleus-cytoplasm ratio, germ cells were classified into five stages: young cells, previtellogenic oocytes (perinucleolar), cortical-alveoli oocytes, vitellogenic oocytes and mature oocytes (Tricas \& Hiramoto, 1989; Vazzoler, 1996; Cárdenas et al., 2008, modified). The maximum diameter of the cytoplasm and the nucleus, of the same cells, were measured. Seventy cells of each different stage of oocyte development were used. Oocytes were only utilized if their nucleus were clearly observed. The nucleuscytoplasm ratio (\%) was calculated by the division of the maximum value of the nucleus diameter in the by the maximum diameter of the respective cell (ND/CD).
Images of different maturation stages of the ovaries were scanned to allow the analysis of oocytes size and their respective nuclei, at each oocyte development stage, using the Image Tool 3.0 software for Windows. In order to verify if in various oocyte development stages there were significant differences in cell diameters and their nuclei $(p<0.05)$, the nonparametric Wilcoxon test was used for the comparison of means, since the data were not homoscedastic ("Bartlett" test) nor normally distributed (Shapiro-Wilk).

Based on the proportion of cells in each stage, phases of ovarian development were determined. The classification of the maturational stages of ovaries was done according to the scale adapted from Hunter et al. (1986), considering the following stages: early maturation, middle maturation, mature and resting.

\section{Results}

\section{Macroscopic description of the ovaries}

The female reproductive system of black triggerfish consists of a pair of ovaries and two short oviducts. The external morphology of gonads showed a clear difference between ovaries and testes, regardless of the degree of gonadal development.

Ovaries were long and their length varied from 1.4 to $7.1 \mathrm{~cm}$ (3.6 \pm 1.3 ), with different shades of color ranging from yellow to pink, according to the development stage. Testes, on the other side, had smaller lengths ranging from 0.8 to $6.5 \mathrm{~cm}(3.0 \pm 1.3)$, colored with shades of white. The degree of ovarian development was classified into four phases, based on morphological characteristics (weight, length and color of gonads):

Phase I - early development (6): ovaries in this stage presented light yellow color, with tiny oocytes and reduced vascularization. Gonad length varied from 1.8 to $3.2 \mathrm{~cm}(2.7 \pm$ 1.2); gonad weight from $4.7 \mathrm{TO} 7.5 \mathrm{~g}(6.3 \pm 12.9)$ and GI varied from 17.5 to $102.0(41 \pm 69)$. Specimens with ovaries in phase I had total length ranging from 19.0 to $30.0 \mathrm{~cm}(26.8 \pm 2.0)$.

Phase II - final development (29): ovaries were relatively bigger when compared to previous stage. Gonad length ranged from 2.9 to $4.5 \mathrm{~cm}$ (3.7 \pm 1.3$)$, gonad weight from 6.4 to $55.6 \mathrm{~g}(14.9 \pm$ $13.5)$ and GI varied from 32.6 to $355.8(83 \pm 72)$. Specimens with ovaries classified as phase II had total length ranging from 20.5 to $30.0 \mathrm{~cm}(26.6 \pm 2.0)$. The color of the ovary in this stage was light pink, with oocytes and blood vessels much more apparent when compared with previous phase.

Phase III - developed (131): Ovaries in this stage were quite voluminous, colored in shades of orange, highly vascularized, with large and abundant oocytes. Length ranged from 1.5 to $7.1 \mathrm{~cm}(4.8 \pm 1.3)$, weight from 9.1 to $82.8 \mathrm{~g}(32.4 \pm 13.8)$ and GI varied from 36.3 to $425.6(178 \pm 75)$. Specimens with ovaries classified in phase III had total length ranging from 23.0 to $30.5(26.1 \pm 2.0)$.

Phase IV - recovery (128): Ovaries in this phase were considerably slackened with relatively thick walls compared to 
previous phases. There was also a significant reduction in ovarian size, with gonad length ranging from 1.4 to $3.2 \mathrm{~cm}(2.4 \pm 1.2)$, gonad weight from 1.4 to $18.7 \mathrm{~g}(3.9 \pm 12.3)$ and GI varying from 6.6 to $62.8(21 \pm 65)$. Specimens with ovaries classified as stage IV had total length ranging from 23.4 to $32.0 \mathrm{~cm}(26.5 \pm 1.9)$.

\section{Microscopic description of the ovaries}

Oocyte development. Ovaries of black triggerfish consist of ovigerous lamellae containing oocytes at different development stages. In addition to germ cells, some somatic components were also observed. These components have an important role in protecting, nourishing and oxygenating oocytes at various development stages.

Based on the shape and oocyte diameters and on the nucleus-cytoplasm ratio and, it was possible to identify of the germ cells in five different stages of oogenesis: young cells, previtellogenic oocytes (perinucleolar), cortical-alveoli oocytes, vitellogenic oocytes and mature oocytes.

Young cells (YC): oogonia and oocytes in early stages of development were considered as young cells (Fig. 2a). They are grouped in the ovigerous lamellae. The cytoplasm of these cells was very scarce, with rounded, central and strongly basophilic nucleus. In this stage it was possible to observe a thin layer of follicle cells around each oocyte, forming a simple epithelium. This epithelium was observed in all the different stages of oogenesis.

There was no large concentration of oocytes in ovaries of black triggerfish in this stage, although it has been found in all stages of ovarian development. The diameter of young cells ranged from 6.09 to $23.42 \mu \mathrm{m}(12.9 \pm 4.4)$.

Previtellogenic oocytes (PVO): Also called oocytes for reserve or perinucleolar (Fig. 2b), this oocyte development stage was characterized by the presence of a considerable increase in volume (more than three times, $p<2.2 \mathrm{e}-16$ ), when compared to the earlier stage with diameters ranging from 24.22 to $83.73 \mathrm{im}(53.5 \pm 15.0)$. At this stage, the cytoplasm was far more defined and easily identifiable, with a more basophilic character than in the previous stage. A nucleus was also observed, always with more than two nucleoli, which were initially in the center of the nucleus, moving to its periphery as the oocyte development progressed. Just as observed in the previous phase, previtellogenic oocytes also occurred in all stages of ovarian development but with higher concentrations in the early stages of maturation and at stage.

Cortical alveoli oocytes (CAO): Cells in this stage were clearly differentiated by the appearance of alveoli, probably filled with lipid material inside the cell cytoplasm, close to the nucleus (Fig. 2c). With oocyte growth, cortical alveoli oocytes increased in number and their sizes became varied. Initially, alveoli were observed near the nuclear region, tending to migrate to the periphery with alveoli development. In this stage, the presence of a discrete zona pellucida was noticed. Oocytes in this stage presented a slight increase in their volume $(p<2.2 \mathrm{e}-16)$ when compared to the previous stage (less than double), with diameters ranging from 47.23 to 125.14 ìm $(83.1 \pm 13.4)$.

Vitellogenic oocytes (VO): Cells in this stage were characterized by a large accumulation of reserve substances, probably proteins and lipids, which will be later used to feed the embryo (Fig. 2d). This accumulation of substances in the cytoplasm causes a great increase in cell volume $(p<2.2 \mathrm{e}-16)$ when compared to other oocyte development stages. The cells presented diameters between 101.82 and 218.86 im (160.4 \pm 26.8 ), more than double of the previous phase. In this stage, the zona pellucida is much more defined and visible.

Mature oocytes (MO): Oocytes in this stage had already completed vitellogenesis. Lipid droplets, as recorded in the previous phases, began to merge and accumulate in large yolk granules in the cytoplasm, causing a significant increase of its volume $(p<2.2 \mathrm{e}-16)$, with cell diameters ranging from 217.64 to $354.73 \mathrm{im}(289.8 \pm 30.7)$. The cytoplasm was no longer basophilic (Fig. 2e). The nucleus became reduced, with no discernible nucleoli, beginning its migration to the cell periphery. The zona pellucida (Fig. 2f) was thicker and little streaked. This was the last phase of oocyte development observed in the ovaries of black triggerfish.

Ovaries of black triggerfish also presented atretic follicles (AF). They are, in general, characterized as a result of oocyte degeneration and consequently reabsorption by phagocytosis. These atretic follicles (Fig.3a) were observed more frequently in the ovaries at the final maturation and mature stages. In addition to the germ cells, whose different phases were characterized above, some somatic structures also present in the ovaries were observed, such as: a) the ovary wall (Fig. 3b), which covers the ovary protecting cells of the germ lineage from the external environment. It is thinner in the early ovarian stages, b) follicular cells (Fig. 2f), observed in all maturation stages occurring freely among ovigerous lamellae or surrounding the oocytes; and c) blood vessels (Fig. 3b) commonly observed near the ovary wall, essential to the oxygenation and nourishment of the cells present in the ovaries.

\section{Oocyte diameter (nucleus-cytoplasm)}

Overall, oocytes showed an increase in its diameter following the development of the cells, with previtellogenic oocytes exhibiting diameters, in average, more than three times those observed in young cells $(p<2.2 \mathrm{e}-16)$. Smaller increases were observed for the cortical alveoli oocytes in relation to the previtellogenic (Fig. 4). The oocyte diameter in the nucleus also increased during oocyte development. Smaller increases occurred in the same way for cell diameter in the nuclei of cortical alveolar oocytes in relation to the previtellogenic ones $(p=4.578 \mathrm{e}-14)$ (Fig. 5). Both oocyte and nuclei diameters differed statistically in all stages (Wilcoxon, $\mathrm{p}<0.05$ ).

Along the process of identification and classification of the different germ cells stages, it was possible to observe the primarily concentration of alveoli filled with lipid materials in 
cortical alveoli oocyte stage. In the subsequent vitellogenic and mature stages, the concentration of yolk globules showed a clear tendency to increase, suggesting an evolution of vitellogenic activity throughout the oocyte development.

Ratio between the nucleus and cell diameters (ND/CD) had the highest values in the early oocyte development stages in young cells (44.09\%), previtellogenic oocytes (46.45\%) and cortical alveoli oocytes (44.82\%). On the other side, the lowest values were observed in the final stages in vitellogenic $(40.19 \%)$ and mature oocytes $(28.83 \%)$.

\section{Description of ovarian maturation stages}

The maturation stages of black triggerfish ovaries were identified and characterized by the type and amount of
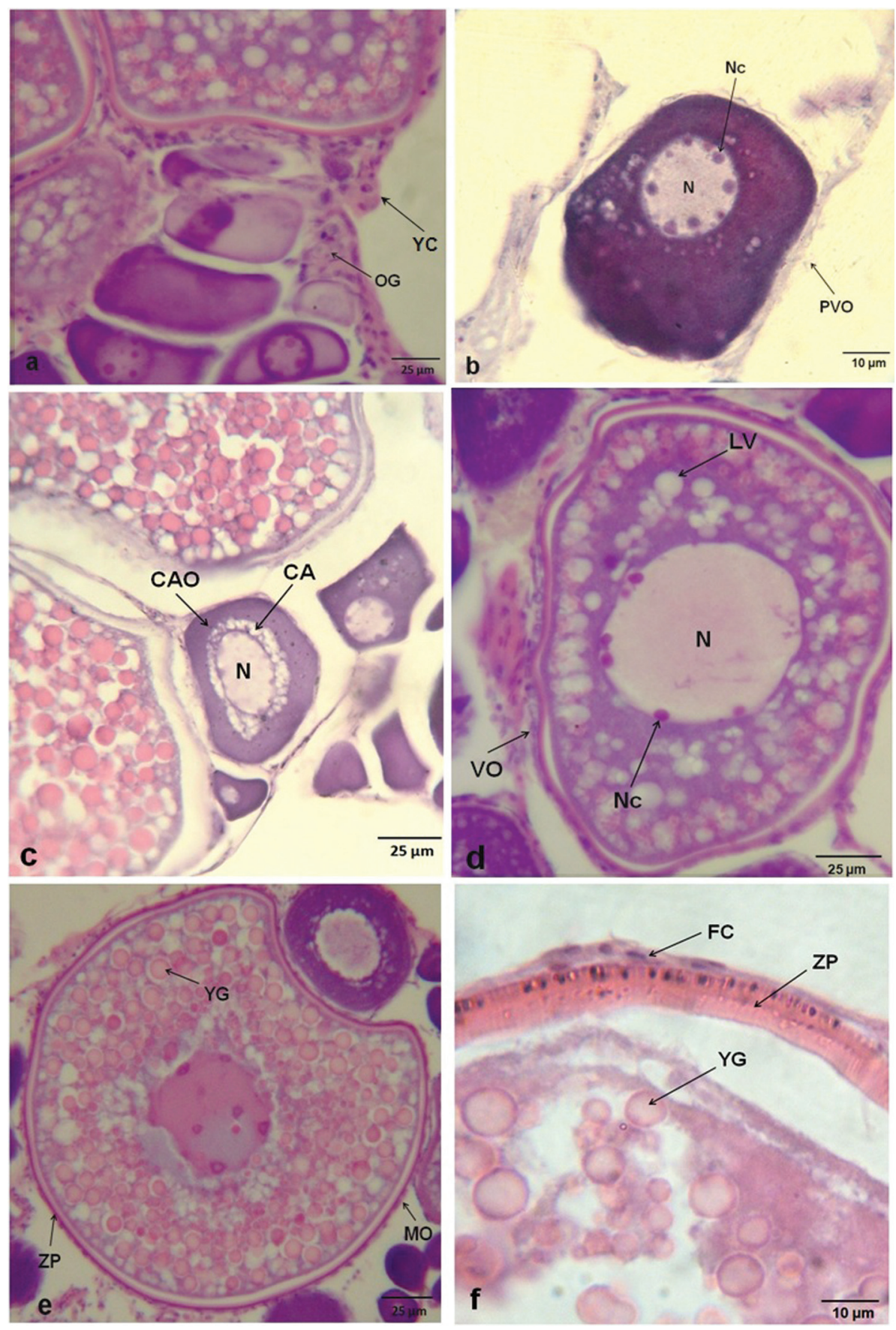

Fig. 2. Photomicrographs of the oogenesis stages of ovaries of black triggerfish caught in the São Pedro e São Paulo Archipelago, between January 2006 and May 2008. (a) YC - young cells, oogonia - OG; (b) PVO - previtellogenic oocytes; (c) $\mathrm{CAO}$ - cortical alveoli oocytes; (d) VO - vitellogenic oocytes; (e) MO - mature oocyte; (f) ZP - zona pellucida (radiated). N nucleus, Nc - nucleolus; FC - follicular cell; LV - lipid vacuole; YG - yolk globules; CA - cortical alveoli. 


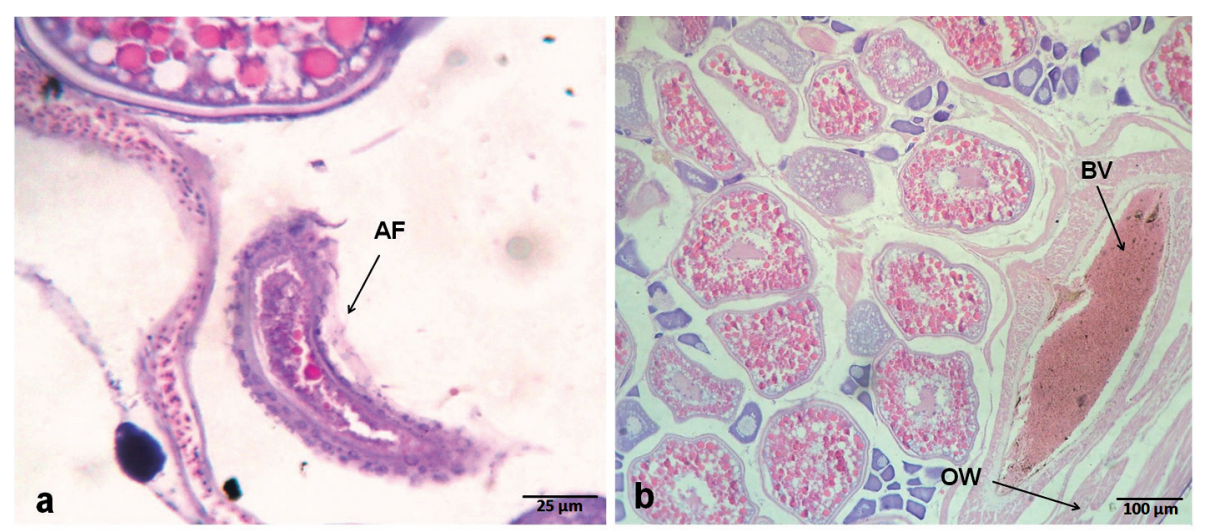

Fig. 3. Photomicrographs of germ cells and somatic structures of ovaries of black triggerfish caught in the São Pedro e São Paulo Archipelago, between January 2006 and May 2008. (a) AF - atretic follicle; (b) BV - blood vessel; and OW - ovary wall.

cells observed in each oogenesis stage (Table 1). Based on the histology of 294 ovaries examined, black triggerfish females were classified into four microscopic stages of maturation: early maturation, middle maturation, mature and resting.

Early maturation (Fig. 6a): This stage, represented by only $2.2 \%$ (6) of the sample, was characterized by abundant presence of young cells, forming small "nests", together with previtellogenic oocytes, cortical alveoli oocytes and small concentrations of vitellogenic oocytes. Follicular cells were also occasionally observed surrounding some oocytes or, more

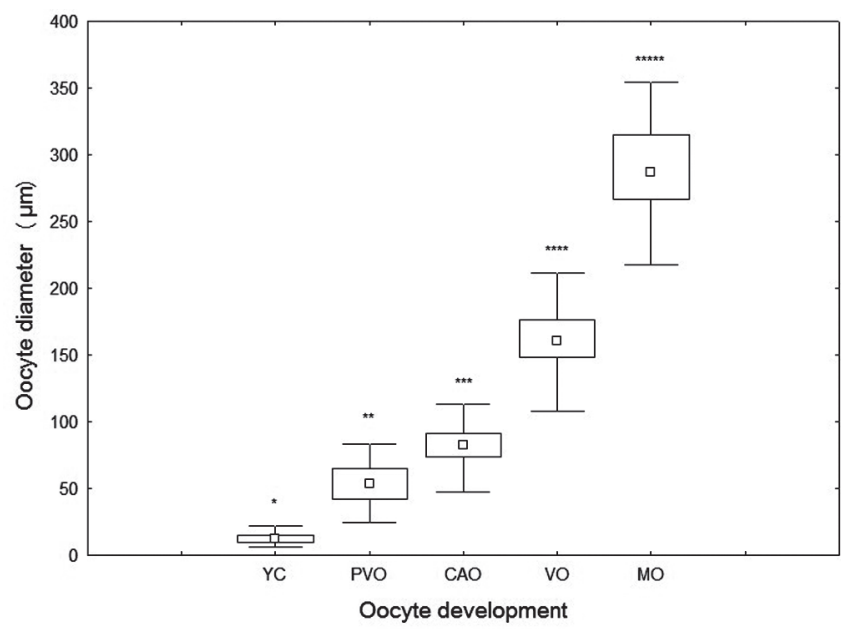

Fig. 4. Mean diameter $(\mu \mathrm{m})$ of oocytes for each oocyte development stage of ovaries of black triggerfish caught in the São Pedro e São Paulo Archipelago, between January 2006 and May 2008. (YC) young cell, (PVO) pre-vitellogenic oocyte, (CAO) cortical alveoli oocytes, (VO) vitellogenic oocytes and (MO) mature oocytes. Asterisks indicate significant differences (Wilcoxon, $p<0.05$ ). frequently, free in ovigerous lamellae, where oocytes were organized. Specimens with ovaries classified at this stage had size of cell ranging from 6.09 to $375 \mu \mathrm{m}(71 \pm 45.16)$.

Middle maturation (Fig. 6b): Represented by $9.9 \%$ (29) of the sample, this stage was characterized by the occurrence of oocytes in all vitellogenesis stages: small concentrations of young cells, previtellogenic and mature oocytes and abundant quantities of cortical alveoli oocytes and vitellogenic oocytes. Blood vessels were frequently observed in histological sections close to the ovary wall. The size of the cells ranged from 7 to $344 \mu \mathrm{m}(85 \pm 66.1)$.

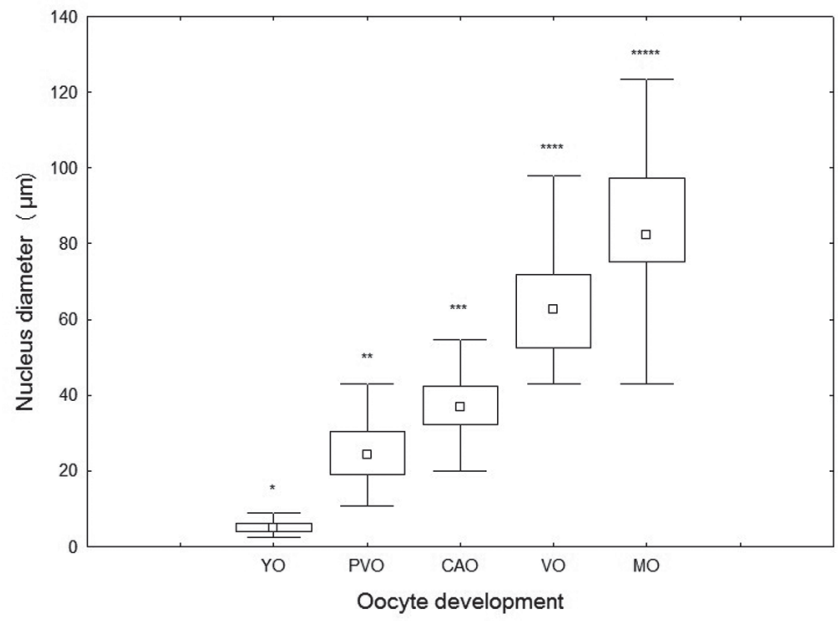

Fig. 5. Mean diameter (ìm) of nuclei of oocytes for each oocyte development stage of ovaries of black triggerfish caught in the São Pedro e São Paulo Archipelago, between January 2006 and May 2008. (YC) young cell, (PVO) pre-vitellogenic oocyte, (CAO) cortical alveoli oocytes, (VO) vitellogenic oocytes and (MO) mature oocytes. Asterisks indicate significant differences (Wilcoxon, $p<0.05$ ). 
Table 1. Ovarian maturation stages of black triggerfish based on the occurrence of different oocyte development stages. (YC) young cell; (PVO) previtellogenic oocyte; (CAO) cortical alveoli oocytes; (VO) vitellogenic oocytes; and (MO) mature oocytes (- absent, + present, ++ frequent,+++ abundant).

\begin{tabular}{cccccc}
\hline Ovarian Maturation & YC & PVO & CAO & VO & MO \\
Stages & & & & & \\
\hline Early Maturation & +++ & +++ & ++ & + & - \\
Middle Maturation & + & + & +++ & +++ & + \\
Mature & + & + & ++ & ++ & +++ \\
Resting & +++ & +++ & + & - & - \\
\hline
\end{tabular}

Mature (Fig. 6c): This stage was the most frequent of the entire sample, with $44.2 \%$ (130). It was characterized by abundant predominance of mature oocytes, which also occurred in the previous stage, but in much lower concentrations. The presence of young cells and previtellogenic oocytes were also observed, in addition to the frequent occurrence of cortical alveoli and vitellogenic oocytes. Follicular cells were also abundantly found surrounding the zona pellucida of mature oocytes. Oocytes were no longer organized in ovigerous lamellae. Specimens with ovaries classified in this stage had size of cells ranging from 11 to $354.7 \mu \mathrm{m}(169 \pm 103.04)$, doubling in diameter when compared to the previous stage.

Resting (Fig. 6d): This stage was the second most observed, representing $43.9 \%$ (129) of the sample. It was characterized by abundant occurrence, almost exclusively, of young cells and previtellogenic oocytes, in addition to the presence of cortical alveoli oocytes but in small concentrations. Follicular cells, although present, did not occur at the same frequency as in the previous stage. Specimens with ovaries classified in this stage had size of cells ranging from 9 to 108 ìm $(39 \pm$ 14.35). The average size of oocytes found at this stage, $39 \mathrm{im}$, was the lowest among all. Ovary wall, however, was much thicker when compared to the other stages.

\section{Discussion}

The ovaries of black triggerfish, $M$. niger, examined in this study were morphologically and structurally similar to those observed in most teleosts (Jalabert, 2005). Based on macroscopic characteristics such as morphology, weight, size, vascularization and color of gonads, ovarian development of many teleosts is commonly classified into five main stages: immature, maturing, mature, spawned, and resting (Vazzoler, 1996). The number of development stages, however, may change according to different authors and species. Sahayak (2005), for example, developed a study on the southeast coast of India reporting only three stages of ovarian maturation: immature, maturing, and mature. The study was based on external characteristics of ovaries and frequency of oocytes diameter of Sufflamen fraenatum, reef fish species also belonging to the family Balistidae. In the present study, based on macro and microscopic characteristics, four reproductive stages in the ovaries of black triggerfish were identified in São Pedro e São Paulo Archipelago. Immature and spawned stages of ovaries, normally observed in other teleosts, were not recorded. The lack of immature individuals is certainly related to the relatively large size of the specimens caught $(>19.0 \mathrm{~cm} \mathrm{TL})$, with smaller individuals probably distributed in deeper and protected regions from SPSPA, inaccessible to the use of fishing gears.

The exclusive use of macroscopic characteristics for the classification of ovarian development in teleost fish has been increasingly criticized. Some authors have warned that using this type of scale may not be adequate, especially for species that have a multiple spawning, since this type of spawning could block the identification of maturation stages without a proper histological analysis (Honji et al., 2006). In the present case, however, the macroscopic scale proposed, based on external aspects of the ovary, seemed adequate to characterize the reproductive development of the species; which probably has a total spawning and a synchronous oocyte development, in two groups (Branco, 2011).

Terminologies and features used to differentiate and identify the distinct stages of an oocyte formation may vary according to the authors and species studied (Abascal \& Medina, 2005). Histological analysis performed on the sample gonads allowed the clear identification of five oocyte development stages (young cells, perinucleolar previtellogenic oocytes, cortical alveoli oocytes, vitellogenic oocytes, and mature oocytes), following a pattern similar to that described for other marine fish species (Wallace \& Selman, 1981, 1990; Grier, 2000). Some of the subdivisions reported by McMillan (2007), nevertheless, have not been observed. The stage of young cells identified for the black triggerfish for example, included oogonia and oocytes in early development stages, are similar to the 'primary growth stage' and the 'chromatin-nucleolar stage', described by McMillan (2007).

In the ovaries of black triggerfish, oogonia were also characterized by forming "nests", as normally observed for fishes (Grier et al., 2007; Quagio-Grassiotto et al., 2011). These "nests", however, occurred eventually isolated or in small groups. This difference can be explained by the predominance of adults (Abascal \& Medina, 2005) and the consequently absence of immature ovaries, which usually have higher concentration of nest-shaped oogonia (Vazzoler, 1996).

The second oocyte development stage for black triggerfish called previtellogenic oocytes, would be equivalent to the second phase of the 'primary growth stage' called by McMillan (2007) perinucleolar phase. Although this stage was considered as a phase included in the primary growth stage by McMillan (2007), in this study it was considered a separate stage due to the clear differentiation between them. The nucleoli concentration in the vicinities of the inner nucleus membrane, i.e., on its periphery, observed at this stage, has been reported for several teleosts, for species inhabiting marine environments as well as freshwater (Wallace \& Selman, 1981; Tricas \& Hiramoto, 1989; Ganeco et al., 2001; Abdalla \& CruzLandim, 2003; Honji et al., 2006; Cárdenas et al., 2008). 


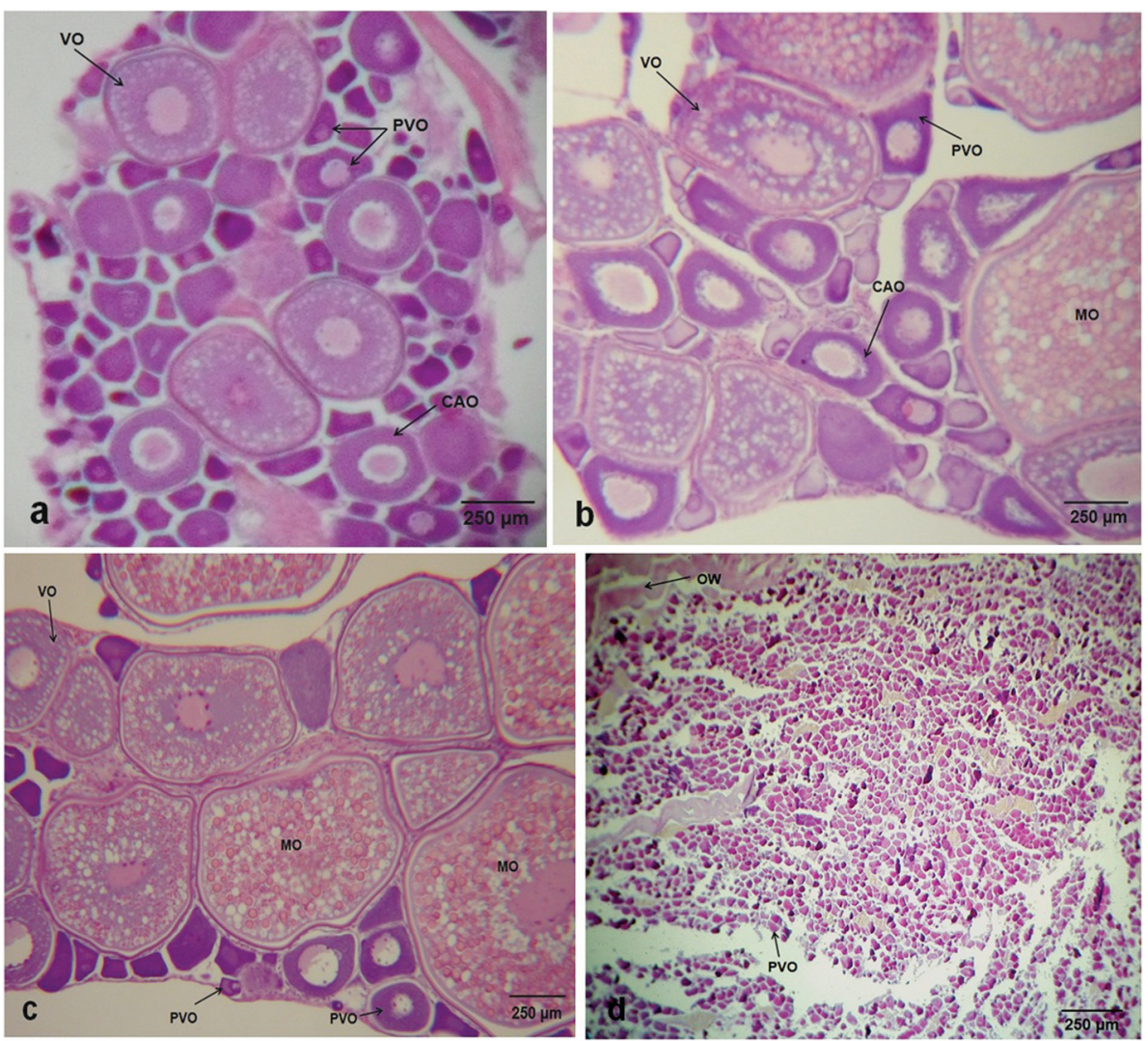

Fig. 6. Photomicrograph of ovaries sections of black triggerfish at different maturation stages. (a) early maturation, (b) middle maturation, (c) mature, and (d) resting. PVO: previtellogenic oocytes; CAO: cortical alveoli oocytes; VO: vitellogenic oocytes; MO: mature oocyte; and OW: ovary wall.

The cortical alveoli and vitellogenic stages were similar to those described by McMillan (2007). The cortical alveoli stage observed in the ovaries of black triggerfish, characterized mainly by the aggregation of small lipid droplets in cell cytoplasm, is a common feature to several teleosts species (Wallace \& Selman, 1981). There are reports, however, that the presence of cortical granules in some teleosts occurs only at the end of the previtellogenic stage (Abdalla \& Cruz-Landim, 2003). Differently from observed in other cases, on this study, oocytes from cortical alveoli stage were marked also by presenting a discrete thin zona pellucida, similar to other teleosts (Mesa et al., 2007). Although this structure in other species may appear only in the late previtellogenic stage (Cárdenas et al., 2008) or only in later stages of the oocyte development (Tricas \& Hiramoto, 1989; Chaves, 1992). The vitellogenic stage of black triggerfish, as in most teleosts, was marked by a significant increase in the oocyte diameters, mainly by the inclusion of lipid droplets in cell cytoplasm, a process that begins in the previous stage by the exogenous accumulation of proteins (Wallace \& Selman, 1981; Abascal $\&$ Medina, 2005). For black triggerfish, lipid droplets seem to form first in the vicinity of the nucleus, contrary to what was reported to Chaetodon multicinctus (Tricas \& Hiramoto, 1989), a species in which yolk globules form first in the cytoplasm periphery, just later migrating into the cell.
The final oocyte development stage identified in the present work, characterized by mature oocytes, was not subdivided into stages as described by McMillan (2007). In most teleosts, the mature oocyte development stage is featured by a rapid increase in follicular volume, depending on the hydration and accumulation of macromolecules. In the present case, the presence of mature oocytes fully hydrated was not registered, contrary to what is usually observed in several marine fish (Honji et al., 2006; Robillard et al., 2008). According to França et al. (2010) and LaFleur et al. (2005) in benthophil species, oocyte hydration is more modest. In general, however, hydration of oocytes during maturation is especially pronounced in fish that have pelagic or floating eggs, occurring in a less pronounced way in species with demersal eggs or not floating ones. Many species of the family Balistidae lay their eggs in the substrate, such as: Pseudobalistes flavimarginatus (Gladstone, 1994), Sufflamen chrysopterum (Ishihara \& Kuwamura, 1996), Rhinecanthus aculeatus (Kuwamura, 1997), Balistes capriscus (Bernardes \& Dias, 2000) e Xanthichthys mento (Kawase, 2003). Another reason for the low frequency of hydrated oocytes is also the short time in which hydration occurs at the moment of spawning, as described by Tricas \& Hiramoto (1989) for Chaetodon multicinctus.

Oocyte diameter of black triggerfish presented a wide range throughout oocyte development. Sahayak (2005) reported for 
S. fraenatus, a species of the same family, a slightly larger variation, from 22 to $462 \mathrm{im}$. According to Ofori-Danson (1990), oocytes of females of $B$. capriscus caught in the spawning period, i.e., females with mature ovaries, had oocytes with a mean diameter of $450 \mathrm{im}$. Bernardes \& Dias (2000) also working with $B$. capriscus, observed values ranging from 75.00 to 399.00 ìm. In all reported studies, the maximum oocyte diameters was larger than the one found in this study. However, the oocyte diameters seem to be characteristic of each species, with their variation being closely linked to the vitellogenic process, i.e., yolk accumulation within cell cytoplasm (Shinozaki, 2008).

The ratio between cell diameters and their nuclei showed the highest values in the early oocyte development stages, probably due to the fact that nuclear activity at this stage was much more intense than the activity of cell cytoplasm, reason why the nucleus would require a larger space in relation to the cell cytoplasm. Contrariwise, the lowest ratio values were recorded in the last stage of cell development, due to the accumulation of yolk material within the cytoplasm; fact which ultimately increases the cell diameter in relation to the nucleus. Such trend has also been recorded for other teleosts (Abascal \& Medina, 2005).

Atretic follicles observed during oocyte development of black triggerfish were much more frequent in ovaries which were close to final maturation or were already mature. The presence of atretic follicles was also recorded eventually in earlier maturation stages as well as in resting ovaries, but in much less frequency when compared with ovaries in final maturation stage and mature. In some teleosts, however, atretic follicles are restricted to resting stage (Ganeco et al., 2001). Atretic oocytes, nevertheless, can occur at any stage of gonad development (Honji et al., 2006), once the degeneration of oocytes or follicular atresia is a process in which, for some reason (environmental or physiological), the oocyte begins to be reabsorbed by the body. Such a phenomenon can occur either in oocytes that have not reached maturity yet, as well as after spawning, in oocytes that, for some reason, have not been eliminated (Ganeco et al., 2001). The atresia process may affect oocyte at any stage of development, although it is described more frequently in maturing and unovulated mature oocytes (Rastogi, 1969; MacMillan, 2007), as it was observed in the present work. According to McMillan (2007) the apparent rarity of small atretic follicles may be due to their earlier disappearance when compared to mature follicles and also due to their small size, which turn them visible in only fewer microscopic sections.

Post-ovulatory follicles are usually observed in fish with ovaries recently spawned or already in recovery after a recent spawning, although they may also be eventually found in mature ovaries (Mesa et al., 2007). The absence of postovulatory follicles in the present case therefore, can be explained by the lack of spawned ovaries among the examined specimens.

Even if complex, the identification and characterization of different oocyte development stages and ovarian maturation found in this survey are extremely important for the designing of future studies related to the reproductive cycle of other balistid species, given the high shortage of knowledge about the reproductive biology of this important group.

\section{Acknowledgments}

The authors are grateful to the SECIRM (Interministerial Commission for Sea Resources), and to $\mathrm{CNPq}$ (Conselho Nacional de Desenvolvimento Científico e Tecnológico, Brazil) for the logistical support.

\section{Literature Cited}

Abascal, F. J. \& A. Medina. 2005. Ultrastructure of oogenesis in the bluefin tuna, Thunnus thynnus. Journal of Morphology, 264: 149-160.

Abdalla, F. C. \& C. Cruz-Landim. 2003. Some histological and ultrastructural aspects of oogenesis in Piaractus mesopotamicus Holmberg, 1887 (Teleostei). Brazilian Journal of Morphological Sciences, 20: 3-10.

Behmer, O. A., E. M. C. Tolosa \& A. G. Freitas-Neto. 1976. Manual de técnicas para histologia normal e patológica. São Paulo, Edart.

Bernardes, R. A. \& J. F. Dias. 2000. Aspectos da reprodução do peixe-porco, Balistes capriscus (Gmelin) (Actinopterygii, Tetraodontiformes, Balistidae) coletado na costa sul do Estado de São Paulo, Brasil. Revista Brasileira de Zoologia, 17: 687696.

Branco, I. S. L. 2011. Biologia reprodutiva do cangulo-preto ( $M$. niger, Bloch, 1789) capturado no Arquipélago de São Pedro e São Paulo - Brasil. Unpublished M.Sc Dissertation, Universidade Federal Rural de Pernambuco, Recife.

Cárdenas, R., M. Chávez, J. L. González, A. P. Espinosa \& L. F. Jiménez-garcía. 2008. Oocyte structure and ultrastructure in the Mexican silverside fish Chirostoma humboldtianum (Atheriniformes: Atherinopsidae). Revista de Biologia Tropical, 56: $1825-1835$.

Carvalho-filho, A. 1999. Peixes da Costa Brasileira. São Paulo, Melro.

Chaves, P. T. C. 1992. Aspectos do desenvolvimento ovocitário no peixe-pulmonado Sul-americano, Lepidosiren paradoxa Fitzinger (Dipnoi). Revista Brasileira de Zoologia, 9: 93-98.

Fariña, A., A. Bellorín, S. Sant \& E. Méndez. 2005. Estructura de la comunidad de peces en un arrecife del Arquipélago Los Monjes, Venezuela. Ciencias Marinas, 31: 585-591.

Feitoza, B. M., R. S. Rosa \& L. A. Rocha. 2005. Ecology and zoogeography of deep reef fishes in Northeastern Brasil. Bulletin of Marine Science, 76: 725-742.

França, G. F., H. J. Grier \& I. Quagio-Grassiotto. 2010. A new vision of the origin and the oocyte development in the ostariophysi applied to Gymnotus sylvius (Teleostei, Gymnotiformes). Neotropical Ichthyology, 8: 787-804.

Fricke, H. W. 1980. Mating Systems, Maternal and Biparental Care in Triggerfish (Balistidae). Zeitschrift für Tierpsychologie, 53: 105-122.

Ganeco, L. N., L. S. O. Nakaghi, E. C. Urbinati, R. Dumont Neto \& L. H. Vasques. 2001. Análise morfológica do desenvolvimento ovocitário de piracanjuba, Brycon orbignyanus, durante o ciclo reprodutivo. Boletim do Instituto de Pesca, 27: 131-138.

Gasparini, J. L. \& S. R. Floeter. 2001. The shore fishes of Trindade Island, Western South Atlantic. Journal of Natural History, 35: 1639-1656.

Gladstone, W. 1994. Lek-like spawning, parental care and mating periodicity of the triggerfish Pseudobalistes flavimarginatus (Balistidae). Environmental Biology of Fishes, 39: 249-257. 
Grace, M., M. Bahnick \& L. Jones. 2000. A preliminary study of the marine biota at Navassa Island, Caribbean Sea. Marine Fisheries Review, 62: 43-48.

Grier, H. J. 2000. Ovarian Germinal Epithelium and Folliculogenesis in the Common Snook, Centropomus undecimalis (Teleostei: Centropomidae). Journal of Morphology, 243: 265-281.

Grier, H. J., M. C. Uribe-Aranzábal \& L. R. Parenti. 2007. Germinal Epithelium, Folliculogenesis, and Postovulatory Follicles in Ovaries of Rainbow Trout, Oncorhynchus mykiss (Walbaum, 1792) (Teleostei, Protacanthopterygii, Salmoniformes). Journal of Morphology, 268:293-310.

Hazin, F.H.V., T. J. Vaske, P. G. Oliveira, B. C. L. Macena \& F. Carvalho. 2008.

Occurrences of whale shark (Rhincodon typus Smith, 1828) in the São Pedro e São Paulo Archipelago. Brazilian Journal of Biology, 68: 385-389.

Honji, R. M., A. M. Vaz-dos-Santos \& C. L. D. B. RossiWongtschowski. 2006. Identification of the stages of ovarian maturation of the argentine hake Merluccius hubbsi Marini, 1933 (Teleostei: Merlucciidae): advantages and disadvantages of the use of the macroscopic and microscopic scales. Neotropical Ichthyology, 4: 329-337.

Hunter, J. R. \& B. J. Macewicz. 1985. Rates of atresia in the ovary of captive and wild northern anchovy, Engraulis mordax. Fishery Bulletin, 83: 119-136.

Hunter, J. R., B. Macewicz \& J. R. Sibert. 1986. The spawning frequency of skipjack tuna, Katsuwonus pelamis, from the South Pacific. Fisheries Bulletin, 84: 895-903.

Ishihara, M. \& T. Kuwamura. 1996. Bigamy or monogamy with maternal egg care in the triggerfish, Sufflamen chrysopterus. Ichthyological Research, 43: 307-313.

Jalabert, B. 2005. Particularities of reproduction and oogenesis in teleost fish compared to mammals. Reproduction Nutrition Development, 45: 261-279.

Kavanagh, K. D. \& E. J. Olney. 2006. Ecological correlates of population density and behavior in circumtropical black triggerfish Melichthys niger (Balistidae). Environmental Biology of Fishes, 76: 387-398.

Kawase, H. \& A. Nakazono. 1992. Reproductive behaviour of the flagtail triggerfish Sufflamen chrysopterus. In: Proceedings of the Seventh International Coral Reef Symposium, 2: 905-907.

Kawase, H. 2003. Spawning behavior and biparental egg care of the crosshatch triggerfish, Xanthichthys mento (Balistidae). Environmental Biology of Fishes, 66: 211-219.

Kuwamura, T. 1997. Evolution of female egg care in Haremic triggerfish, Rhinecanthus aculeatus. Ethology, 103: 1015-1023.

LaFleur, G. F., D. Raldúa, M. Fabra, O. Carnevali, N. Denslow, R. A. Wallace \& J. Cerdà. 2005. Derivation of major yolk proteins from parental vitellogenin, and alternative processing during oocyte maturation in Fundulus heteroclitus. Biology of Reproduction, 73: 815-824.

Lobel, P. S. \& R. E. Johannes. 1980. Nesting, eggs and larvae triggerfishes (Balistidae). Environmental Biology of Fishes, 5: 251-252.

Martins, A. S., G. Olavo \& P. A. S. Costa. 2007. Padrões de Distribuição e Estrutura de Comunidades de Grandes Peixes Recifais na Costa Central do Brasil. Biodiversidade da fauna marinha profunda na costa central brasileira. Museu Nacional, 24: 45-61.

McMillan, D. B. 2007. Fish histology: Female Reproductive Systems. Pp. 68-78. Canada, Springer. [COMPLETAR REFERÊNCIA]
Mesa, M., V. Caputo \& J. T. Eastman. 2007. Gametogenesis in the dragonfishes Akarotaxis nudiceps and Bathydraco marri (Pisces, Notothenioidei: Bathydraconidae) from the Ross Sea. Antarctic Science, 19: 64-70.

Ofori-Danson, P. K. 1990. Reproductive ecology of the triggerfish, Balistes capriscus from the Ghanaian coastal waters. Tropical Ecology, 31: 1-11.

Price, J. H. \& D. M. John. 1980. Ascension Island, South Atlantic: a survery of inshore benthic macro-organisms, communities, and interactions. Aquatic Botany, 9: 251-278.

Quagio-Grassiotto, I., H. Grier, T. S. Mazzoni, R. H. Nóbrega \& J. P. A. Amorim. 2011. Activity of the Ovarian Germinal Epithelium in the Freshwater Catfish, Pimelodus maculatus (Teleostei: Ostariophysi: Siluriformes): Germline Cysts, Follicle Formation and Oocyte Development. Journal of Morphology, 272: 1290-1306.

Rastogi, R. K. 1969. The occurrence and significance of ovular atresia in the fresh water mud-ell, Amphipnous cuchia (Harm.). Acta Anatomica, 73: 148-160.

Robillard, E., C. S. Reiss \& C. M. Jones. 2008. Reproductive biology of bluefish (Pomatomus saltatrix) along the East Coast of the United States. Fisheries Research, 90: 198-208.

Sahayak, S. 2005. Reproductive biology of the masked triggerfish Sufflamen fraenatus. Journal of the Marine Biological Association of India, 47: 70-76.

Sazima, I., C. Sazima, J. M. Silva-Jr. 2006. Fishes associated with spinner dolphins at Fernando de Noronha Archipelago, Tropical Western Atlantic: na update and overview. Neotropical Ichthyology, 4: 451-455.

Schaeffer, M. B. \& C. J. Orange. 1956. Studies of the sexual development and spawning of yellowfin tuna (Neothunnus macropterus) and skipjack (Katsuwonus pelamis) in the three areas of the Eastern Pacific Ocean, by examination of gonads. Inter-American Tropical Tuna Comissioon Buletin, 1: 281-349.

Shinozaki, M. R. A. 2008. Biologia reprodutiva do guaimum, Cardisoma guanhumi Latreille, 1828 (Decapoda: Gecarcinidae) na Região de Aracati, Unpublished M.Sc. Dissertation, Universidade Federal Rural de Pernambuco, Recife, 90p.

Thresher, R. E. 1980. Reef Fish - Behavior and Ecology on the Reef and in the Aquarium. Pp. 124-127. Florida, Palmetto Publishing Company.

Tricas, T. C. \& J. T. Hiramoto. 1989. Sexual differentiation, gonad development, and spawning seasonality of the Hawaiian butterflyfish, Chaetodon multicinctus. Environmental Biology of Fishes, 25: 111-124.

Vazzoler, A. E. A. M. 1996. Biologia da reprodução de peixes teleósteos: teoria e prática. Pp. 32-42. Edum, SBI.

Wallace, R. A. \& K. Selman. 1981. Cellular and dynamic aspects of oocyte Growth in Teleosts. American Zoologist, 21: 325-343.

Wallace, R. A. \& K. Selman. 1990. Ultrastructural aspects of oogenesis and oocyte growth in fish and amphibians. Journal of Electron Microscopy Technique, 16: 175-201.

West, G. 1990. Methods of Assessing Ovarian development in Fishes: a Review. Australian Journal of Marine and Freshwater Research, 41: 199-222.

Submitted February 6, 2012 Accepted July 8, 2013 by Clarice Fialho Published September 30, 2013 